表 8 炭素絾維の生産・出荷量 ${ }^{1)}$ (単位 $: \mathrm{t}$ )

\begin{tabular}{c|r|c}
\hline 年 & 生産量 & 出荷量 \\
\hline 2009 年 & 7,985 & 7,368 \\
\hline 2010 年 & 13,359 & 12,095 \\
\hline 2011 年 & 16,483 & 13,037 \\
\hline 前年対比 (\%) & 123 & 108 \\
\hline
\end{tabular}

（注）生産量に比べ出荷量が少ないのは自家消費による。

ンセプトカー発表など，関連するニュースが大きな注目を集 めた。PAN系は国内 3 社が世界生産量の 7 割を占める中, 需 要は海外が 9 割を超える。韓国・中国を中心としたアジアの 急速な需要拡大, 及び欧州での自動車用途・再生可能エネル ギー用途増加への対応を図り, 海外生産・開発拠点の増強計 画を各社が発表した。またりサイクル技術の研究が進められ ている。ピッチ系は風力発電用, 放熱用ほか各種新規用途の 開拓が進められた。表 8 に炭素瀻維の生産・出荷量を示す。

\section{7. ナノカーボン}

グラフェンが引き続き注目を集め続けた。基礎研究が旺盛 に実施される一方, 透明導電膜や太陽電池, 高速導電素子分 野での期待から, 高品質・低コスト試料合成法や構造評価法 の確立，あるいは製品開発に直接つながる物性についての研 究開発が進められた。

カーボンナノチューブ (CNT) では複合材料開発が本格化 し，樹脂やゴムとの複合化技術の進展，当該用途向けCNTの 量産や新規の分散，また海外企業の国内市場参入が報じられ た。

フラーレンは再生可能エネルギー利用への社会的期待から 有機薄膜太陽電池用途として注目され，また次世代半導体材 料用としての進展など,引き続き研究開発が進められた。

\section{文 献：References}

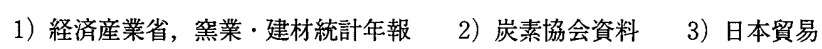
統計 4）経済産業省, 化学工業統計年報

\section{8 石炭灰の利用}

1.はじめに

日本の一次エネルギー総供給量に占める石炭の割合は, 1973年の石油危機以降漸増し, 現在約 $20 \%$ を占める重要な工 ネルギー源となっている。電力業界では, 石油危機以降エネ ルギーの多様化が特に重要視されてきたが, 特に東北大震災 以後は, 電力の需要が逼迫するなかで, 石炭火力発電所の重 要性が増していくものと思われる。

地球温暖化の観点からは，二酸化炭素の発生量だけみると， 同等の電気を得るために石炭は天然ガスと比べると 2 倍近く の二酸化炭素発生量になるが，日本の石炭火力発電所の効率 は世界でもトップクラスであり，日本の石炭火力発電技術を， 米国, 中国, インド等の発電効率の悪い石炭火力発電所に適
用すれば，大幅な二酸化炭素排出削減効果(日本全体の年間二 酸化炭素排出量に匹敵する量)が得られると試算されている。

石炭火力発電所から排出される残渣は, 欧米では CCPS (Coal Combustion Products) として定義されており，それは石 炭灰だけでなく, クリンカーアッシュ(ボトムアッシュ), 脱 硫石高，FBC灰，IGCCスラグ等を含んだものとして定義され ている。

これらの材料の主要有効利用用途としては, 日本ではセメ ントの原材料があげられるが, 最近のセメント産業の大幅な 減産体制のもとでは, 他の有効利用方策を見出すことが, 急 務と考えられる。

ここでは，日本におけるCCPsの現況のうち石炭灰に関して 述べることとする。

\section{2. 石炭灰の現状}

(1)石炭火力発電所の分布と石炭灰の種別

経済産業省の「平成 22 年度電力供給計画の概要」1)によれ ば, 全電力発電設備に占める石炭火力発電の設備割合として

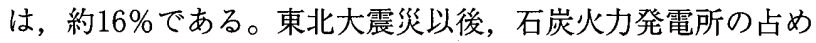
る割合は $16 \%$ 程度を維持ないし, 上回り推移していくものと 予想される。

日本における石炭火力発電所は，全国に分布している(図 1 参照)。そのほとんどの石炭火力発電所が, 海に面して立地し ていることが大きな特徴である。

また，各発電所においてそれぞれ回収されるJIS石炭灰にも 幅（ I 種〜IV種）がある。大崎, 荻田については, PFBC（加 圧流動床）での炉内脱硫タイプなので, カルシウムが多い石 炭灰が排出される。今後, 電力需要の関係で老朽化した発電 設備をリプレイスする動きが活発化するものと考えられる。

\section{(2) 石炭灰の発生量と石炭使用量}

石炭灰の発生量と石炭使用量について，最近 6 力年間を表 1 に, 1994年度からの推移を図 2 に示す。1994年度での石炭 灰の発生量は, 2010 年度の約半分程度 (6,526千トン: 電気事 業 4,725千トン, 一般産業 1,801 千トン) であった。1994年度 から 1998 年度までは緩やかに増加し，1999 年度から 2005 年 度頃までは，増加傾向を示していたが，2005年以降は微妙に 増減している。2010年度 (平成 22 年度) の石炭灰の発生量は, 11,903千卜ンに達しており, そのうち電気事業分が $75 \%$ 程度 を占めており，その他は一般産業分である。

石炭灰の有効利用量と理立量との関係は，図 3 に示すとお りである。2010年度 (平成 22 年度) は, 石炭灰発生量 11,903 千トンのうち有効利用量が 11,522 千トンで, 石炭灰有効利用 率は $96.8 \%$ であり，埋立量は 380 千トンである。

\section{(3) 石炭灰分野別利用量}

石炭灰分野別利用量の推移について，図 4 に示す。石炭灰 は, ダム, 原子力発電所など大型コンクリート構造物に大量 に使用されている一方で，建材，道路材料，肥料，地盤改良 材などにも利用されている。ダム, 原子力発電所等への利用 


\begin{tabular}{|c|c|c|c|c|c|c|c|}
\hline 地理 & 繁新 & 解在的 & 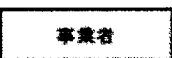 & & & & \\
\hline \multirow{3}{*}{ 北满遭 } & 鬲政 & Axin & 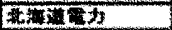 & & & & \\
\hline & th & 北海棓 & 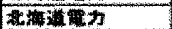 & & & & \\
\hline & 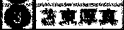 & 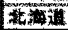 & 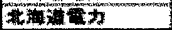 & & to & & 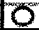 \\
\hline \multirow{6}{*}{ 雪站 } & ffet & क & 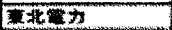 & & 0 & & 0 \\
\hline & 整的 & $38 \mathrm{~s}$ & 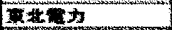 & & 0 & & Lo \\
\hline & 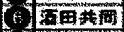 & turk & 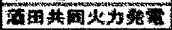 & & 0 & & 10 \\
\hline & 萧称 & min & 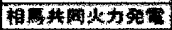 & & & & \\
\hline & פ本 & Wn & Th & & 0 & & \\
\hline & 広里 & 衆巣 & 東京雷力 & & & & \\
\hline \multirow{2}{*}{ 闝堡 } & 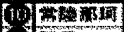 & 柍 & 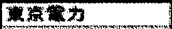 & & & & \\
\hline & 6 于 & क tili & FUBAs & & 0 & & \\
\hline 中䅸 & 带 & 如 & 中部贵力 & & 0 & & \\
\hline \multirow{3}{*}{ 非莶 } & Euturest & Eu & Athes & & & & 10 \\
\hline & th太五 & E[II & 牙零力 & & 0 & & \\
\hline & 项 & 轠 & Hers & & 0 & & \\
\hline \multirow{2}{*}{ 闑造 } & De & 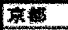 & Defs & & & & \\
\hline & 秒 & IfII & Exhas & & & & 10 \\
\hline \multirow{6}{*}{$中$} & सs & (ratu & क日E & & & & \\
\hline & Her & $\pi$ & Tatas & & 0 & & \\
\hline & X捔 & सמ & क日an & & & & \\
\hline & En & 曋根 & 中心an & & 0 & & 0 \\
\hline & EA小开田 & 40 & 中心e力 & & 10 & & \\
\hline & Th & W0 & 中国象为 & & & & \\
\hline \multirow{6}{*}{ 国 } & 4t & as & garsh & & 10 & & 0 \\
\hline & 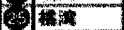 & IIt & Dinms & & & & \\
\hline & 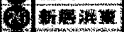 & क्w & 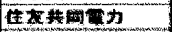 & & & & \\
\hline & 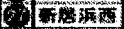 & Sol & 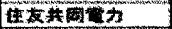 & & & & \\
\hline & 西策 & 2i & Bust & (o) & 0 & & 0 \\
\hline & E生ii & $\mathrm{B}$ & 隹的向力 & & & & \\
\hline \multirow{6}{*}{ 为州 } & (20) & 相要 & 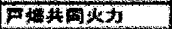 & & & & \\
\hline & \#五 & Ir & 九列为 & & & & \\
\hline & 相溥 & IIn & rum & & 10 & & \\
\hline & 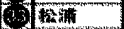 & 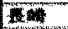 & TrARs & & 10 & & \\
\hline & no & 巷觜 & 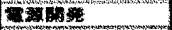 & & 10 & & \\
\hline & 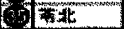 & W & 九ATh & & 0 & & \\
\hline \multirow{3}{*}{ 冲棬 } & It:m & 虿 & 沖梱为 & & & & \\
\hline & EIII & 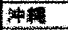 & 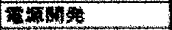 & & 0 & & \\
\hline & $\sqrt{\text { tin }}$ & 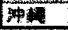 & 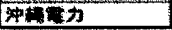 & & & & \\
\hline
\end{tabular}

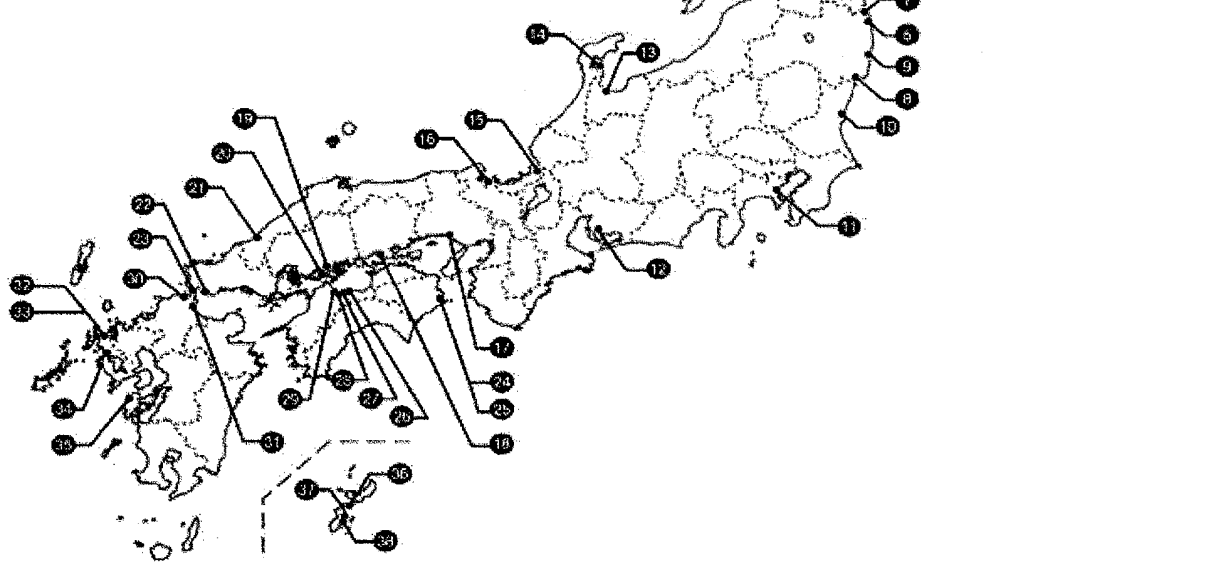

図 1 石炭火力発電所の分布 ${ }^{12)}$

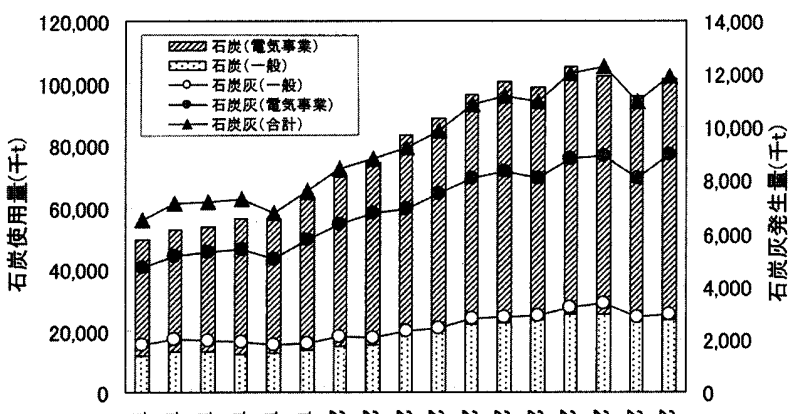

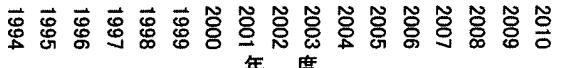

図 2 石炭灰の発生量と石炭使用量 ${ }^{3)}$

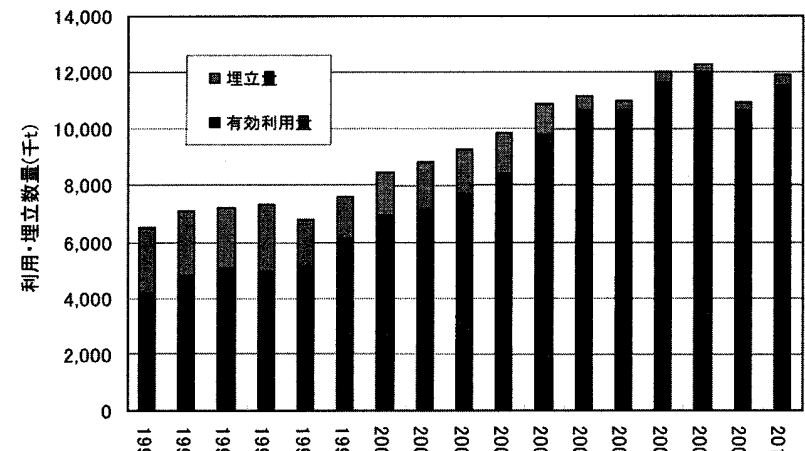

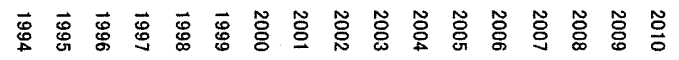
图3 石炭灰の有效利用蘁と埋立量引 
表 1 石炭灰発生量と石炭使用量（最近 6 力年) 3

単位：千トン

\begin{tabular}{|c|c|c|c|c|c|c|c|}
\hline 項 & 目 & 2005 年度 & 2006 年度 & 2007 年度 & 2008 年度 & 2009 年度 & 2010 年度 \\
\hline \multirow{3}{*}{ 石炭使用量 } & 電気事業 & 78,092 & 75,017 & 79,813 & 76,729 & 72,095 & 77,896 \\
\hline & 一般産業 & 22,257 & 23,240 & 25,290 & 25,159 & 23,475 & 23,316 \\
\hline & 計 & 100,349 & 98,257 & 105,103 & 101,888 & 95,570 & 101,212 \\
\hline \multirow{3}{*}{ 石炭灰発生量 } & 電気事業 & 8,334 & 8,097 & 8,802 & 8,934 & 8,096 & 8,950 \\
\hline & 一般産業 & 2,818 & 2,872 & 3,192 & 3,351 & 2,856 & 2,953 \\
\hline & 計 & 11,152 & 10,969 & 11,994 & 12,285 & 10,952 & 11,903 \\
\hline
\end{tabular}

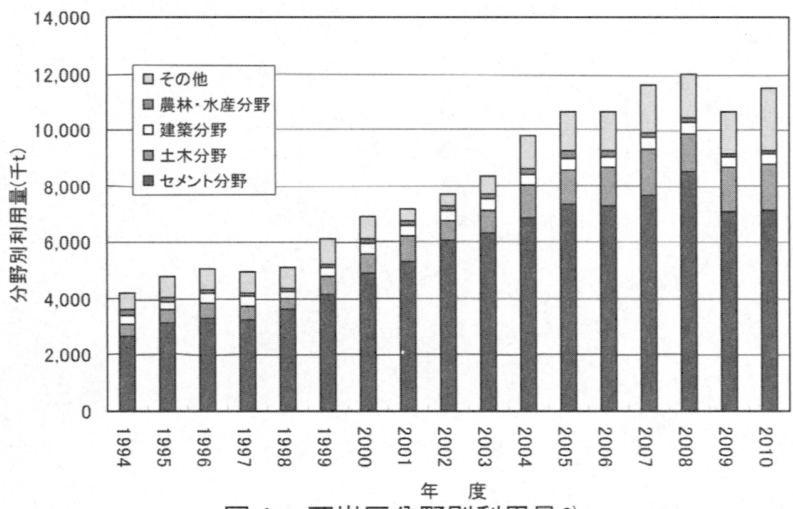

表 2 各種セメントの二酸化炭素排出量原単位 ${ }^{4}$

\begin{tabular}{l|c}
\hline \multicolumn{1}{c}{ セメントの種類 } & 二酸化炭素排出量原単位 $\left(\mathrm{kg}-\mathrm{CO}^{2} / \mathrm{t}\right)$ \\
\hline ポルトランドセメント & 771.0 \\
\hline 高炉セメントB 種 & 464.8 \\
\hline フライアッシュセメントB 種 & 617.0 \\
\hline
\end{tabular}

(注)「セメントの LCIデータの概要」(社)セメント協会 (2011 年 8月）のデー夕による。

図 4 石炭灰分野別利用量

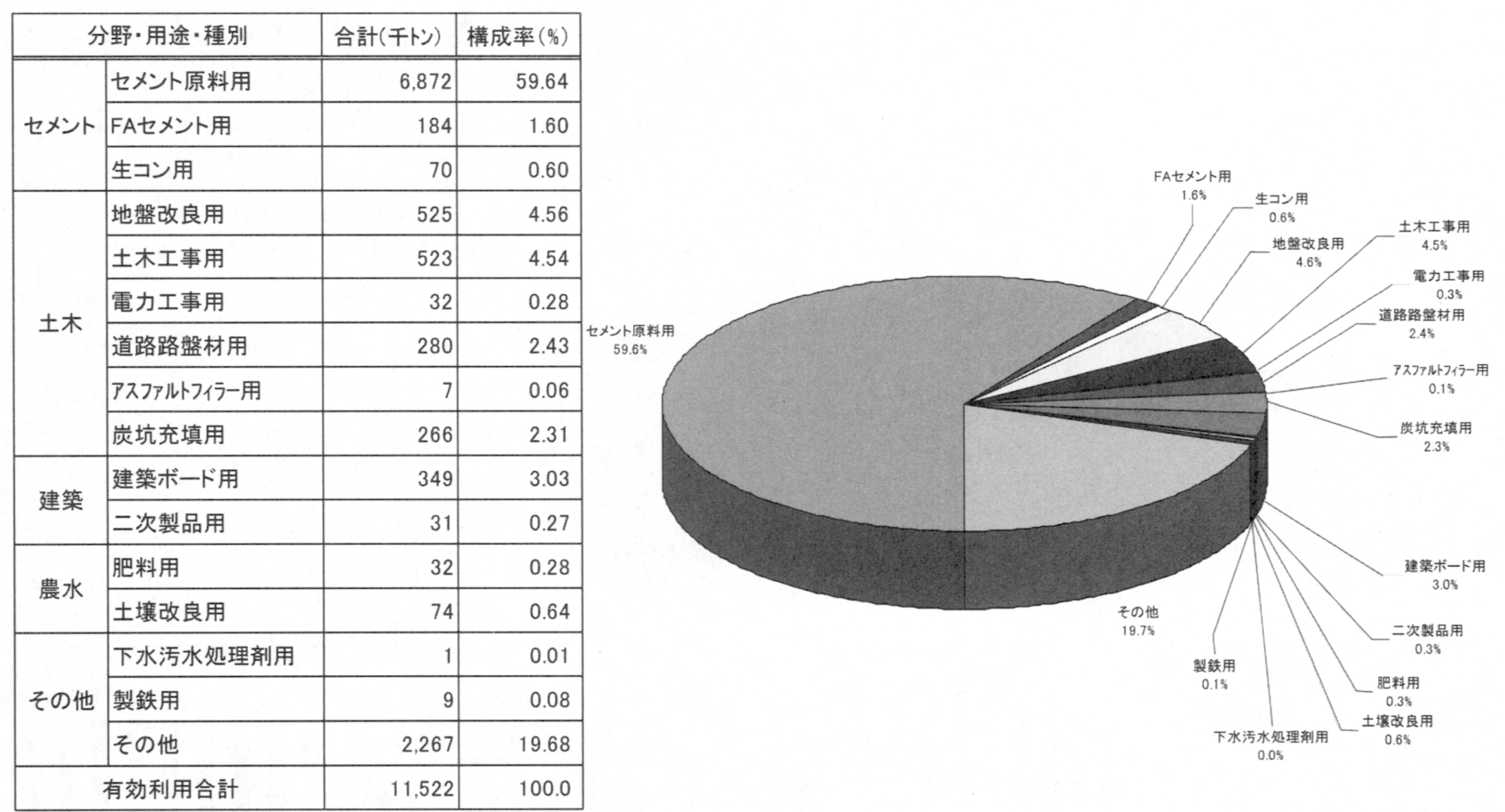

図 5 石炭灰用途別利用状況（2010 年度） ${ }^{3)}$

は多量ではあるが，一時的であり，建材，肥料等への利用は 定常的である。今後は，定常的な有効利用用途先を増やして いくべきである。

2010 年度 (平成 22 年度) の石炭灰分野別利用量は, 図 5 に 示すとおり, 有効利用量全体 11,522 千トンのうち, セメント 分野 7,126 千トン, 土木分野 1,633 千トン，建築分野 380 千卜
ン，農林·水産分野106千トン，その他 2,278 千トンなど，多 岐にわたって資材や原料として利用されている。最も多いの はセメント分野で，約 $62 \%$ を占めており，そのほとんどがセ メントの原材料に使われている。このような利用形態は, 世 界でも極めて特殊なものである。 


\section{3. 石炭灰利用ついての課題と展望}

(1) グリーンマテリアルとして（主にセメントの混和材料と して)

材料の面からは，石炭灰をセメントの混和材として用いる ことにより，大幅な環境負荷低減を図ることが期待されてい る。石炭灰のコンクリートの製造過程における材料面でのメ リットは，第一にセメントの原材料に対して混和材を代替す ることにより，天然の資材が消費されないという点である。ま た，セメントの混和材料として利用すると，他の原単位に比 較して非常に大きな二酸化炭素排出量原単位を持つセメント の二酸化炭素排出量原単位を，ほほ置換した分たけ低減する ことができる。

石炭灰の二酸化炭素排出量原単位がほほ 0 と見なせるのは, その排出 (生産) に至るエネルギーは, 石炭火力発電所での電 力生産のほうにカウントされていると考えているからである。 セメントの混和材としてフライアッシュ（高炬スラグ微粉 末）を用いた場合のセメントの二酸化炭素排出量原単位を表 2 に示す。ポルトランドセメントの一部をそれぞれフライ アッシュ（高炬スラグ微粉末）で置換していることから，そ れらの二酸化炭素排出量原単位は，表に示すように，ポルト ランドセメントの值よりも大幅に小さいことがわかる。今後, 石炭灰を積極的に混和材として利用することが二酸化炭素の 低減に大きく寄与することになるといえる。

\section{(2) 今後の展望}

今後, 日本の石炭灰の有効利用がセメント産業に大きく依 存していることは既に述べたとおりであるが，埋立処分する 場所の確保も難しくなっており，有効利用用途の拡大が望ま れている。今後は，ユーザーに有効利用しやすい性状の石炭
灰を排出するために，発電所側（燃焼側）での様々な石炭種・ 使用条件に対して, 石炭灰性状を調整できる技術の開発も重 要なものとなると思われる。コスト低減の観点から，幅広い 燃料の利用が期待され，燃料はより多様化するものと考えら れる。亜瀝青炭については, 一部の微粉炭火力で導入が始ま り,さらにバイオマスなど, 再生可能エネルギーとして今後 その有効利用が重要視されているものもあり，これらを幅広 く利用できるようにする技術が不可欠となると思われる。 ユーザーへの供給に関しては, 従来特定の発電所からの供 給がなされていたが，最近アッシュセンターで複数の発電所 の石炭灰を集めて品質を均質化して出荷する試みがなされて いる。ユーザーとしては，一定の品質の材料を常に入手でき るようになり，またアッシュセンターに一定の量の石炭灰が 確保されるので，そこからニーズに応じて入手することが計 画的に提案できるようになると考えられる。今後, このよう なアッシュセンターが日本国内で, 適切に配置され機能して いくことが望まれる。

また，環境性の観点からは，用途に応じて，環境対策を配 慮した技術開発の重要性が高まってくると思われる。

また東北大震災以後, 新たなエネルギーバランスが指向さ れ，石炭火力発電所の重要性がより増していくことが予想さ れる。

\section{文 献：References}

1）土木学会, 循環型社会に適合したフライアッシュコンクリートの最新利 用技術，コンクリートライブラリー[132]，(2009）２）日本フライアッ シュ協会, 石炭灰パンフレット, (2004) 3）(財)石炭エネルギーセン 夕一, 石炭灰全国実態調查報告書 (平成 22 年度実績), (2012) 4)（社） セメント協会, セメントの LCI データの概要, (2011) 